\title{
Implementasi Program Paku Bumi dalam Konteks Penguatan Pendidikan Karakter di MIN 1 Kota Malang
}

\author{
Imroatul Fadliyah*, Sa'dun Akbar, Muchtar \\ Universitas Negeri Malang, Jl. Semarang No. 5 Malang, Jawa Timur, Indonesia \\ *Penulis korespondensi, Surel: imroatulfadliyah97@gmail.com
}

Paper received: 5-7-2021; revised: 23-7-2021; accepted: 30-7-2021

\begin{abstract}
Character education is very important for students to be formed as early as possible. MIN 1 Malang City applies character education with a PAKU BUMI program. The objectives of this study are (1) the concept of the PAKU BUMI program; (2) the implementation of the PAKU BUMI program in strengthening character education; (c) character education values embedded in students through the PAKU BUMI program; (d) supporting factors and inhibiting factors; (e) student behavior as a result of the implementation of the PAKU BUMI program. This research uses a qualitative approach with the type of case study research. Researchers as a key instrument. Data collection techniques by observation, interviews, and documentation. Data analysis includes data reduction, data presentation, drawing conclusions. The validity of the data using techniques of increasing persistence and triangulation techniques. In this study, researchers reveal and explain in detail the implementation of the PAKU BUMI program. The results of the study found that the PAKU BUMI program is an arrangement of the national curriculum of the Ministry of Religion, the vision and mission of madrasas, and circulars of the Ministry of Religion of Malang City with the aim of increasing the KI 1 and KI 2. The PAKU BUMI program is an intracurricular activity in accordance with presidential regulation number 872017 concerning strengthening character education. There are several activities from the PAKU BUMI program in strengthening character education through (a) fardhu prayers and sunnah prayers; (b) dhikr and prayers after prayers and daily prayers; (c) reading the Koran and memorizing juz 30; (d) spread greetings; (e) fasting in Ramadan and fasting sunnah; (f) morality; (g) life skills or life skills. The PAKU BUMI program is able to bring out unique and distinctive character values in activities. In accordance with the provisions of the presidential regulation on strengthening character education. The PAKU BUMI program has an impact on the behavior of students who are honest, responsible, disciplined, and independent for themselves and those around them.
\end{abstract}

Keywords: implementation; PAKU BUMI; character education

\begin{abstract}
Abstrak
Pendidikan karakter sangat penting bagi siswa dengan dibentuk sedini mungkin. MIN 1 Kota Malang menerapkan pendidikan karakter dengan sebuah program PAKU BUMI Tujuan penelitian ini untuk (1) konsep program PAKU BUMI; (2) implementasi program PAKU BUMI dalam penguatan pendidikan karakter; (c) nilai-nilai pendidikan karakter yang tertanam pada siswa melalui program PAKU BUMI; (d) faktor pendukung dan faktor penghambat; (e) perilaku siswa sebagai dampak implementasi program PAKU BUMI. Penelitian ini menggunakan pendekatan kualitatif dengan jenis penelitian studi kasus. Peneliti sebagai instrumen kunci. Teknik pengumpulan data dengan observasi, wawancara, dan dokumentasi. Analisis data meliputi reduksi data, penyajian data, menarik kesimpulan. Keabsahan data menggunakan teknik meningkatkan ketekunan dan teknik triangulasi. Pada penelitian ini peneliti mengungkapkan dan menjelaskan secara detail implementasi program PAKU BUMI. Hasil penelitian didapatkan bahwa program PAKU BUMI merupakan susunan dari kurikulum nasional Kementerian Agama, visi misi madrasah, dan surat edaran Kementerian Agama Kota Malang dengan tujuan untuk meningkatkan pada KI 1 dan KI 2. Program PAKU BUMI merupakan kegiatan intrakurikuler yang sesuai dengan peraturan presiden nomor 87 tahun 2017 tentang penguatan pendidikan karakter. Terdapat beberapa kegiatan dari program PAKU BUMI dalam penguatan pendidikan karakter melalui (a) shalat fardhu dan shalat sunnah; (b) dzikir dan doa setelah salat serta doa sehari-hari; (c) membaca al-quran dan hafalan juz 30; (d) menebar salam; (e) puasa Ramadhan dan puasa sunnah; (f) akhlakul karimah; (g) life skill atau kecakapan hidup.
\end{abstract}


Program PAKU BUMI mampu memunculkan nilai-nilai karakter yang unik dan khas dalam kegiatan. Sesuai dengan ketetapan peraturan presiden tentang penguatan pendidikan karakter. Program PAKU BUMI berdampak pada perilaku siswa yang jujur, tanggung jawab, disiplin, dan mandiri untuk dirinya dan sekitarnya.

Kata kunci: implementasi; PAKU BUMI; pendidikan karakter

\section{Pendahuluan}

Kesiapan menghadapi persaingan global salah satunya dengan mempersiapkan sumber daya manusia yang berkualitas dari aspek ilmu pengetahuan, kecerdasan, iptek, moral maupun akhlak. Selaras dengan pendapat Sonhadji (2012) bahwasanya pendidikan di Indonesia harus mengarah pada pembentukan watak yang mulia dengan penguasaan iptek agar siswa yang dihasilkan mampu mengendalikan teknologi dan bukan individu yang dikendalikan teknologi. Berkembangnya teknologi secara cepat pada era globalisasi memudahkan manusia untuk memenuhi kebutuhan. Membuat manusia bisa mengakses berbagai hal sebebasnya hingga banyak informasi yang positif maupun negatif. Globalisasi bisa menjadi mata pisau yang sangat berguna maupun bisa juga menjerumuskan, tergantung bagaimana manusia untuk menyikapinya.

Perkembangan teknologi dalam dunia pendidikan sangat mempengaruhi cara anak dalam bersikap. Teknologi digunakan oleh beberapa anak untuk mengasah kemampuan diri mereka agar memperoleh prestasi, akan tetapi beberapa anak gagal dalam menggunakan teknologi sehingga menimbulkan masalah pada dirinya dan orang lain. Hal tersebut juga menimbulkan beberapa permasalahan di sekolah dasar. Pada tahun 2014 terjadi kasus kekerasan siswa SD yang diduga efek bermain game dan bullying (KPAI, 2014). Tahun 2019 terjadi kasus perpeloncoan siswa SD kepada temannya, dengan hasil pengakuan pelaku sering menonton video kekerasan dan terinspirasi dari media sosial yaitu YouTube (Detik, 2019). Tahun 2020 terjadi kasus tawuran dengan senjata tajam yang melibatkan siswa SD karena dipicu oleh coretan vandalisme (Detik, 2020). Pada tahun 2020 kasus bullying hingga kekerasan fisik yang menyebabkan depresi siswa SD (Okezone, 2020). Berdasarkan hasil pengamatan peneliti di lapangan, ditemukan contoh permasalahan seperti mengejek sesama teman, membuang sampah sembarangan, minimnya berbahasa yang sopan, abai dalam beribadah, dan kurangnya menjaga lingkungan sekitar menimbulkan adanya krisis karakter dikalangan anak sekolah dasar saat ini. Adanya krisis karakter dapat diatasi melalui pendidikan di sekolah.

Sekolah menjadi salah satu tempat pembentukan karakter anak, karena di sekolah terdapat proses penanaman pendidikan karakter sebagai peran penting dalam mewujudkan bangsa yang berkualitas. Selaras Rajasa (2007) dalam Muslich (2011), pendidikan sebagai arena untuk membangkitkan suatu karakter bangsa yang dapat mengakselerasi pembangunan serta mobilisasi potensi domestik agar daya saing bangsa meningkat. Hal tersebut menjadikan alasan pendidikan karakter perlu dikuatkan.

Penyelenggaran pendidikan karakter diharapkan menumbuhkan karakter yang baik pada anak. Selaras dengan pendapat Sutarna (2018) pendidikan karakter sebagai dasar dalam pembentukan karakter bangsa yang berkualitas dengan tidak mengabaikan nilai-nilai sosial. Pendidikan karakter juga harus diberikan kepada anak sejak usia sekolah khususnya sekolah dasar, agar kedepannya memiliki perilaku baik yang dapat diterapkan dalam kehidupannya. 
Hal itu juga sesuai dengan tujuan pendidikan nasional pada Undang-Undang RI No. 20 tahun 2003 tentang Sistem Pendidikan Nasional Pasal 3, yang berisi

Pendidikan Nasional berfungsi mengembangkan kemampuan dan membentuk watak serta peradapan bangsa yang bermartabat dalam rangka mencerdaskan kehidupan bangsa, bertujuan untuk berkembangnya potensi peserta didik agar menjadi manusia yang beriman dan bertakwa kepada Tuhan Yang Maha Esa, berakhlak mulia, sehat, berilmu, cakap, kreatif, mandiri dan menjadi warga negara yang demokratis serta bertanggung jawab.

Tujuan pendidikan nasional di atas merupakan tujuan pendidikan yang akan dicapai oleh pemerintah. Pendidikan karakter pada siswa harus dimaksimalkan agar siswa memiliki ketahanan sekaligus bisa mengantisipasi potensi di era globalisasi. Pendidikan karakter perlu diperhatikan dengan baik bagi satuan pendidikan. Sekolah mewujudkan tujuan tersebut diperlukan upaya atau program yang menunjang keberhasilan terlaksanakannya pendidikan karakter sesuai arahan pemerintah. Pemerintah juga melakukan tujuan pendidikan untuk karakter bangsa. Sesuai Permendikbud Nomor 20 tahun 2018 tentang penguatan pendidikan karakter yang mengharapkan siswa memiliki karakter yang baik yang menerapkan nilai-nilai yang ada pada Pancasila dalam pendidikan karakter.

Salah satu sekolah yang menerapkan program pendidikan karakter yaitu MIN 1 Kota Malang yang terletak di tengah kota Malang. MIN 1 Kota Malang merupakan pendidikan sekolah dasar di bawah naungan Kementrian Agama Republik Indonesia. Sekolah ini mementingkan karakter siswanya sesuai visi sekolah yaitu "Terwujudnya lulusan madrasah yang beriman, berakhlak mulia dan berprestasi". Hal ini mengisyaratkan bahwa MIN 1 Kota Malang sebagai lembaga pendidikan yang menerapkan pendidikan karakter di dalamnya. Saat ini sekolah tersebut menerapkan pembelajaran jarak jauh karena pandemi Covid-19. Sehingga untuk mengontrol siswa agar memiliki pembiasaan karakter yang baik perlu adanya pembiasaan.

Berdasarkan observasi awal peneliti di MIN 1 Kota Malang menemukan bahwa sekolah menerapkan gerakan penguatan pendidikan karakter yang bertujuan untuk membentuk karakter siswa yang baik. Walaupun saat ini pembelajaran dilakukan dengan jarak jauh, MIN 1 Kota Malang tetap melakukan penguatan pendidikan karakter untuk siswanya. MIN 1 Kota Malang memiliki program yang bernama PAKU BUMI singkatan dari pengembangan akhlak karakter ubudiyah budaya islami. Program tersebut bertujuan untuk membentuk karakter siswa dan membantu orang tua dalam mengontrol akhlak siswa pada masa pandemi saat ini, agar menjadi pembiasaan yang baik untuk siswa MIN 1 Kota Malang. Program tersebut menekankan karakter ubudiyah yang memiliki buku panduan serta penilaian setiap dua minggu sekali. Saat pandemi seperti sekarang, orang tua turut serta dalam pembimbingan anak di rumah. Bukan hanya sekolah, orang tua berkontribusi dalam pendidikan karakter anak sebagai partner yang berperan dalam membantu dan pendukung untuk mempersiapkan segala sesuatu yang dibutuhkan anaknya secara fisik, finansial maupun moral. Berdasarkan studi pendahuluan yang dilakukan peneliti, maka penelitian dilaksanakan di MIN 1 Kota Malang.

Penelitian terdahulu yang relevan dengan topik ini dilakukan oleh Luthfi Assagaf tahun 2019 dengan judul “Analisis Pendidikan Karakter Program 11 Pembiasaan Emas Siswa MAN 2 Jakarta" yang menunjukkan bahwa Program Emas Siswa madrasah ini mencerminkan nilainilai Pancasila dan program ini mendukung dalam pembentukan karakter peserta didik. Penelitian lain yang relevan juga dilakukan oleh Ziyadatur Rif'ah Agustina tahun 2020 dengan 
judul "Implementasi Keterampilan Ibadah (Ubudiyah) dalam Membentuk Karakter Religius Siswa di MI Ma'arif NU Ass'adah Bungah Gresik" yang menunjukkan bahwa dengan melaksanakan pembiasaan seperti mengajarkan doa, shalat dhuha dan dhuhur berjamaah, membaca istighosah dan tahlil, menerapkan 5S, melakukan sedekah, menjaga kebersihan dan melaksanakan PHBI (peringatan hari besar islam). Karakter yang tumbuh seperti sikap disiplin, jujur, rajin ibadah, rendah hati, tanggung jawab dan peduli. Penelitian lain yang relevan juga dibuat oleh Arum Lismawati Putri tahun 2020 dengan judul "Penguatan Pendidikan Karakter Religius Melalui Program Pembelajaran Agama Islam Terpadu di SDIT Yabunayya Malang" yang menunjukkan bahwa Program pembelajaran agama islam terpadu di SDIT Yabunayya Malang terlaksana dengan baik menghasilkan karakter religius kepada siswa SDIT Yabunayya Malang. Berdasarkan hasil ketiga penelitian terdahulu, membuktikan bahwa penguatan pendidikan karakter dapat dengan bantuan program yang dibuat oleh sekolah dan perlu adanya pembiasaan. Bantuan dari beberapa pihak juga diperlukan dalam membentuk karakter.

Hasil uraian tersebut, peneliti tertarik dan ingin mengetahui kajian lebih lanjut tentang program yang ada di MIN 1 Kota Malang yaitu PAKU BUMI. Berdasarkan latar belakang masalah tersebut, peneliti bermaksud melakukan penelitian yang berjudul "Implementasi Program PAKU BUMI dalam Konteks Penguatan Pendidikan Karakter di MIN 1 Kota Malang”.

\section{Metode}

Penelitian ini menggunakan pendekatan kualitatif, karena penelitian ini didasarkan pada rumusan yang ingin diamati yang mengharuskan peneliti mengamati, memahami, menguraikan, dan menelaah data yang didapatkan berdasarkan fenomena di lapangan. Menurut Ulfatin (2015) penelitian kualitatif merupakan penelitian yang melihat kealamiahan atau naturalistik dari suatu peristiwa. Penelitian ini menggunakan rancangan penelitian studi kasus, karena hanya memiliki satu lokasi dan satu kasus yang digali secara rinci dan terus menerus sampai menemukan pemecahan masalah sesuai dengan fokus peneliti. Pernyataan itu dikuatkan dengan ungkapan Ulfatin (2015) mengenai "studi kasus adalah metode penelitian yang memusatkan perhatian pada suatu kasus secara intensif dan rinci". Kasus yang diangkat dalam penelitian ini adalah implementasi program PAKU BUMI dalam konteks penguatan pendidikan karakter di MIN 1 Kota Malang yang diteliti secara sistematis, faktual dan akurat. Lokasi penelitian dilaksanakan di Madrasah Ibtidaiyah Negeri 1 Kota Malang yang berada di Jl. Bandung No.7C Penanggungan, Kec. Klojen Kota Malang kode pos 65113, telepon (0341) 551176. Waktu penelitian dilaksanakan mulai dari tanggal 9 April - 30 April 2021.

Sumber data diperoleh dari subjek penelitian atau sumber informasi. Subjek penelitian dapat diperoleh dari kepala madrasah, koordinator bidang kesiswaan, koordinator unit program PAKU BUMI, wali kelas, siswa, dan orang tua siswa MIN 1 Kota Malang. Sumber data penelitian ini berupa hasil observasi, wawancara dan dokumentasi. Penelitian ini menggunakan sumber data primer dan sumber data sekunder. Teknik pengumpulan data yang digunakan peneliti dalam penelitiannya menggunakan tiga teknik yaitu: (1) observasi; (2) wawancara; (3) dokumentasi. Pada teknik observasi peneliti mengamati secara langsung menggunakan pedoman observasi, serta mengingat dan mencatat hasil temuan di lapangan Pada teknik wawancara peneliti mengumpulkan data dari kepala madrasah, koordinator bidang kesiswaan, koordinator unit program PAKU BUMI, wali kelas, siswa, dan orang tua siswa dengan instrumen wawancara. Pada teknik dokumentasi peneliti mengambil dokumen berupa file maupun foto saat melakukan penelitian. Setelah melakukan kegiatan pengumpulan data, selanjutnya 
peneliti akan melakukan teknik analisis data. Tahap analisis data merupakan tahap yang terpenting dalam suatu metode penelitian, karena pada tahap ini akan memperoleh suatu hasil yang dapat memecahkan suatu permasalahan dari penelitian. Teknik analisis data yang dilaksanakan dalam penelitian ini menggunakan teknik analisis data menurut Sugiyono (2017) yang mengemukakan terdapat tiga tahapan pada saat analisis data yaitu reduksi data, penyajian data, penarikan kesimpulan.

Salah satu hal penting yang harus disediakan dalam penelitian yaitu instrumen penelitian. Pada penelitian ini, instrument utama pada penelitian yaitu peneliti sendiri. Selain itu, peneliti bertindak sendiri dan peneliti berperan sebagai pengumpul dan penganalisis data menggunakan metode triangulasi sumber yaitu pedoman observasi, pedoman wawancara, dan pedoman dokumentasi. Oleh sebab itu, dengan metode triangulasi data akan memudahkan peneliti dalam melakukan Analisa data yang telah ditemukan. Pada penelitian ini dilaksanakan dengan tahap penelitian kualitatif yaitu tahap perencanaan penelitian, tahap pelaksanaan penelitian, tahap pelaporan.

\section{Hasil dan Pembahasan}

Berdasarkan beberapa hal yang diperoleh melalui analisis seperti yang dijelaskan di atas, dapat dikemukakan beberapa hasil yang diperoleh penelitian ini yaitu meliputi implementasi program PAKU BUMI dalam konteks penguatan pendidikan karakter di MIN 1 Kota Malang yang dapat dijabarkan sebagai berikut:

\subsection{Konsep Program PAKU BUMI Di MIN 1 Kota Malang}

Program PAKU BUMI merupakan program intrakulikuler. Berdasarkan hasil penelitian bahwa program PAKU BUMI dilatar belakangi oleh kurikulum Nasional Kementerian Agama, visi misi MIN 1 Kota Malang, dan surat edaran dari Kementrian Agama Kota Malang pada awal tahun 2020. MIN 1 Kota Malang adalah sekolah dasar yang berada dibawah Kementrian Agama sehingga kurikulum yang digunakan adalah kurikulum nasional Kementrian Agama dengan menambah muatan agama yaitu lima bidang studi agama seperti quran hadis, fiqih, akidah akhlak, sejarah kebudayaan islam, bahasa arab. Terdapat Visi MIN 1 Kota Malang dengan harapan bahwa siswa maupun lulusan mempunyai keyakinan dan kepercayaan kepada Allah SWT, memiliki akhlak yang baik dan berprestasi baik akademik maupun non akademik. Surat edaran dari Kementrian Agama Kota Malang yang keluar pada awal tahun 2020 berisi tentang penambahan porsi pada KI 1 dan KI 2. KI 1 tentang spiritual dan KI 2 tentang sosial. Hal ini menandakan bahwa program PAKU BUMI adalah kegiatan intrakurikuler, yang hanya saja pelaksanaannya berada di rumah karena pandemi covid. Sejalan dengan Kemendikbud (2018) bahwa kegiatan intrakurikuler merupakan kegiatan pembelajaran yang dilakukan oleh madrasah secara teratur, terjadwal, dan wajib diikuti siswa yang berisi berbagai kegiatan untuk meningkatkan Standar Kompetensi Lulusan melalui Kompetensi Dasar yang dimiliki siswa serta dilaksanakan terus menerus setiap hari.

Tujuan program PAKU BUMI adalah untuk membina dan membentuk akhlakul karimah dan karakter siswa serta memperkuat nilai agama yang diterapkan dalam kehidupan seharihari. Menurut Sutarna (2018) pendidikan karakter bertujuan meningkatkan mutu penyelenggara serta hasil pendidikan yang mengarah kepada pencapaian dalam pembentukan karakter dan akhlak mulia anak dengan utuh, terpadu, dan seimbang sesuai norma serta nilai. Pendidikan tidak hanya belajar tentang akademik saja, tetapi membentuk karakter juga sangat 
penting yang berkaitan dengan perkembangan otak kanan. Sejalan dengan Masmur Muslich (2011) sistem pendidikan dini saat ini terlalu berorientasi pada pengembangan otak kiri dan kurang memperhatikan perkembangan otak kanan. Hal ini sejalan dengan temuan peneliti bahwa rata-rata siswa MIN 1 Kota Malang dibentuk bukan hanya untuk nilai akademik saja, tetapi kegiatan yang membentuk karakter siswa juga penting agar keduanya seimbang. Dari pernyataan tersebut MIN 1 Kota Malang menerapkan pendidikan karakter untuk siswa melalui program PAKU BUMI.

Berdasarkan hasil penelitian bahwa program PAKU BUMI dibuat oleh Kepala MIN 1 Kota Malang dengan dibantu koordinator bidang. Sejalan dengan Kemendikbud (2018) bahwa kepala sekolah diharapkan menjadi pemimpin yang dapat dipercaya dan visioner yang dimana memiliki visi untuk ke depan tentang kekhasan, keunikan, dan kualitas madrasah yang disusun. Membuat dari perencanaan, pelaksanaan hingga penilaian. Kepala MIN 1 Kota Malang membentuk sebuah koordinator unit program PAKU BUMI yang terdiri dari ketua koordinator dan tim PAKU BUMI yang beranggota 1 sekretaris, 3 pemateri, dan 6 koordinator kelas untuk memudahkan dalam merealisasikan program PAKU BUMI.

Tim PAKU BUMI membuat sebaran materi yang akan disebarkan melalui google form dengan link yang dimana setiap pertemuan, materi yang diberikan memiliki target dan berbeda pada jenjang kelas. Karena adanya pandemi sehingga dilakukan secara online dengan pemantauan dari MIN 1 Kota Malang dengan bantuan orang tua. Program ini dilakukan semua kelas dari kelas 1 hingga kelas 6 dengan dibantu wali kelas dalam proses komunikasi. Hal ini sejalan dengan Solihin (2009) bahwa program adalah kegiatan-kegiatan yang dibuat dalam jangka waktu tertentu yang mendukung untuk tercapainya tujuan organisasi. Dari pernyataan tersebut MIN 1 Kota Malang telah merancang program PAKU BUMI guna menanamkan pendidikan karakter kepada siswa.

Berdasarkan hasil penelitian bahwa materi program PAKU BUMI sesuai dengan KI 1 dan KI 2. KI 1 berkaitan dengan spiritual dan KI 2 berkaitan dengan nilai sosial. Pada KD dibuat sesuai karakteristik madrasah agar dapat dispesifikan lagi sesuai kebutuhan di MIN 1 Kota Malang. Hal ini sejalan dengan temuan penelitian bahwa materi yang diberikan setiap jenjang kelas berbeda dan memiliki tahapan agar target dapat terpenuhi. Perwujudan tiap jenjang kelas juga berbeda, kalau ada materi yang sama tetapi tingkatan yang berbeda. Pada KI 1 memiliki KD terkait (a) shalat fardhu dan shalat sunnah; (b) dzikir dan doa setelah salat serta doa sehari-hari; (c) membaca Al-Quran dan hafal juz 30; (d) menebar salam; (e) puasa Ramadhan dan puasa sunnah. Pada KI 2 memiliki KD terkait (a) akhlakul karimah (jujur, disiplin, tanggung jawab, santun) dan (b) life skill (kecakapan hidup). Dari pernyataan tersebut MIN 1 Kota Malang menyiapkan materi dengan target yang berbeda pada jenjang kelas dengan menanamkan pendidikan karakter kepada siswa.

\subsection{Implementasi Program Paku Bumi Dalam Konteks Penguatan Pendidikan Karakter}

Program PAKU BUMI terdiri dari berbagai macam kegiatan antara lain shalat fardhu dan shalat sunnah, dzikir dan doa setelah salat serta doa sehari-hari, membaca Al-Quran, menebar salam, puasa Ramadhan dan puasa sunnah, akhlakul karimah, life skill atau kecakapan hidup. Program PAKU BUMI merupakan program intrakurikuler yang harus diikuti oleh semua siswa MIN 1 Kota Malang. Sesuai dengan peraturan presiden nomor 87 tahun 2017 tentang 
penguatan pendidikan karakter pasal 6 berbunyi "penyelenggaraan PPK pada satuan pendidikan jalur pendidikan formal dilakukan secara terintegrasi dalam kegiatan intrakurikuler, kokurikuler, dan ekstrakurikuler". Pada penanaman pendidikan karakter yang dilakukan oleh MIN 1 Kota Malang telah sesuai dengan peraturan presiden bahwa terdapat kegiatan intrakurikuler. Pernyataan sejalan dengan Akbar (2015) bahwa pendidikan karakter adalah upaya yang memiliki tujuan untuk menjadikan karakter yang baik. Karakter yang baik dinyatakan hidup dengan benar dalam hubungan seseorang dengan tuhannya, sesama, lingkungan, bangsa negara serta dirinya.

Program PAKU BUMI dalam menanamkan karakter dilakukan secara bertahap agar dapat membentuk pendidikan karakter dengan maksimal. Penanaman karakter diterapkan MIN 1 Kota Malang sejak siswa masuk di madrasah agar menjadi langkah awal dalam menanamkan karakter kepada siswanya. Penanaman dilakukan secara bertahap dan terus menerus agar tertanam dalam diri siswa dan diharapkan sesuai dengan ajaran agama Islam. Penanaman karakter tidak bisa secara instan karena diperlukan kerjasama dan komitmen dalam pelaksanaannya secara terus menerus dan tanpa henti. Sejalan dengan pendapat Kemendikbud (2018) bahwa kerja sama dan komitmen dari pihak sekolah dan orang tua menjadi faktor kunci keberhasilan pelaksanaan pendidikan karakter di masing-masing sekolah tersebut.

Shalat merupakan kewajiban bagi semua umat agama Islam yang bertujuan untuk beribadah kepada Allah. Shalat fardhu terdiri dari shalat shubuh, dhuhur, ashar, maghrib, dan isya yang disarankan untuk shalat pada awal waktu. Shalat sunnah yang dibiasakan oleh MIN 1 Kota Malang yaitu shalat sunnah qabliyah, ba'diyah, dhuha, tahajjud, tarawih, dan witir. Kegiatan keagamaan ini bisa dilakukan berjamaah maupun sendiri di masjid dan di rumah serta melaksanakan shalat pada awal waktu. Melalui kegiatan ini siswa diharapkan akan lebih sadar atau memiliki kesadaran dalam beribadah. Sejalan dengan pendapat Akbar (2015) bahwa upaya yang memiliki tujuan untuk menjadikan karakter yang baik yang dinyatakan hidup dengan benar dalam hubungan seseorang dengan tuhannya, sesama, lingkungan, bangsa negara serta dirinya.

Kegiatan dzikir dan doa setelah salat serta doa sehari-hari dilakukan dengan belajar sesuai tingkatan jenjang kelas. Tidak langsung diajarkan semua, tetapi secara bertahap. Terdapat target yang berbeda setiap jenjang kelas agar siswa belajar secara bertahap. Pada kelas rendah siswa diajarkan untuk berdoa dalam melakukan sesuatu kegiatan. Saat makan siswa dianjurkan untuk berdoa bahkan saat selesai makan. Saat tidur juga dianjurkan untuk membaca doa dan saat bangun tidur juga membaca doa. Pada kelas tinggi siswa sudah diajarkan untuk berdzikir dan doa setelah shalat untuk diamalkan. Hal ini bertujuan untuk mengetahui bacaan dan memuji tuhan dan rasulnya agar lebih taat kepada ajaran agama Islam. Hal tersebut membuat siswa melakukan kegiatan-kegiatan lain yang positif bisa berdoa terlebih dahulu.

MIN 1 Kota Malang membudayakan untuk setiap hari membaca Al-Quran dengan metode ummi. Kegiatan ini berisi membaca Al-Quran dan hafalan juz 30 dalam kegiatan seharihari. Terdapat target yang berbeda setiap jenjang kelas agar siswa dapat menghafal juz 30 . Sejalan dengan peraturan presiden nomor 87 Tahun 2017 tentang penguatan pendidikan karakter pasal 7 ayat 5 berbunyi bahwa kegiatan keagamaan sebagaimana dimaksud pada ayat (4) dapat dilaksanakan paling sedikit melalui pesantren kilat, ceramah keagamaan, katekisasi, 
retreat, baca tulis Al-Quran dan kitab suci lainnya. Kegiatan ini menerapkan baca tulis AlQuran. Pada kelas rendah, siswa sudah ditargetkan untuk menghafal surat-surat yang ada dalam juz 30 dengan bertahap dan urut. Pada kelas tinggi, sudah banyak siswa yang hafal dengan juz 30 karena sebelum lulus minimal siswa sudah hafal juz 30. Tetapi jika siswa sudah hafal juz 30 dan belum sampai kelas enam maka dianjurkan untuk melanjutkan hafalan pada juz 1 dan seterusnya tetapi melalui kegiatan tasmi akbar juz 30 yang dimana siswa ujian bacaan surat-surat pendek.

Menebar salam dapat menumbuhkan rasa saling cinta terhadap sesama muslim dan diri sendiri. Kegiatan ini merupakan kebaikan yang dilestarikan oleh MIN 1 Kota Malang agar sebagai seorang umat agama Islam. Kegiatan ini membiasakan siswa untuk saling bertegur sapa dan bersalaman dengan orang sekitar khususnya orang tua, guru, teman, tetangga, dan lingkungan sekitar. Kita sebagai manusia yang hidup di dunia ini tentunya ingin merasakan sesuatu yang dinamakan dengan kedamaian tanpa adanya konflik. Pada pengembangan karakter lebih berkaitan dengan memaksimalkan pada perkembangan otak kanan yaitu afektif, empati, dan rasa. Sejalan dengan pendapat Masmur Muslich (2011) sistem pendidikan dini saat ini terlalu berorientasi pada pengembangan otak kiri dan kurang memperhatikan perkembangan otak kanan.

Puasa bertujuan untuk melatih kesabaran dan ketaatan kepada Allah sesuai rukun islam yang ke empat yang merupakan kewajiban bagi umat agama Islam. Kegiatan puasa diamalkan oleh Siswa MIN 1 Kota Malang dengan melaksanakan puasa Ramadhan sesuai perintah agama Islam. Tetapi pada kelas rendah khususnya kelas satu yang masih berlatih untuk berpuasa. Terdapat puasa wajib dan sunnah yang dimana puasa adalah rukun islam yang keempat. Puasa Ramadhan merupakan puasa di bulan Ramadhan yang wajib dilaksanakan umat Islam bagi yang mampu. Puasa sunnah merupakan puasa yang bila dikerjakan akan mendapat pahala. Pada kelas rendah khususnya kelas satu yang masih berlatih untuk berpuasa. Terdapat satu atau dua siswa kelas satu yang melaksanakan puasa Ramadhan setengah hari, sisanya melaksanakan puasa Ramadhan sampai maghrib. Pada kelas tinggi, Siswa sudah melaksanakan puasa Ramadhan sesuai perintah yaitu full sampai waktu maghrib. Kegiatan puasa sunnah, siswa MIN 1 Kota Malang masih difokuskan untuk melaksanakan puasa sunnah hari Senin dan Kamis.

Kegiatan akhlakul karimah ini ditanamkan kepada diri siswa untuk mengamalkan amalan dalam kehidupan sehari-hari sebagai contoh suri tauladan dalam berakhlak mulia. Akhlakul karimah sebagai perbuatan yang baik sesuai dengan ajaran agama Islam sehingga senantiasa disenangi oleh manusia dan baik di mata Allah. Siswa harus memiliki akhlakul karimah untuk pedoman dalam menjalankan kehidupan sehari-hari. Sejalan dengan pendapat Sutarna (2018) bahwa pendidikan karakter bertujuan meningkatkan mutu penyelenggara serta hasil pendidikan yang mengarah kepada pencapaian dalam pembentukan karakter dan akhlak mulia anak dengan utuh, terpadu, dan seimbang sesuai norma serta nilai. Kegiatan akhlakul karimah telah disusun oleh MIN 1 Kota Malang sesuai dengan materi yang sesuai dengan karakteristik madrasah untuk bekal dalam hidup siswa.

Kegiatan life skill atau kecakapan hidup ini ditanamkan kepada diri siswa untuk beradaptasi dalam menghadapi tantangan kehidupan sehari-hari agar memenuhi kebutuhan dirinya dan membantu orang tua di rumah. MIN 1 Kota Malang memiliki rancangan untuk kegiatan life skill atau kecakapan hidup untuk siswanya, sehingga bertujuan agar siswa menjadi 
pribadi yang lebih mandiri dan tangguh dalam melaksanakan kewajiban untuk memenuhi kebutuhan pribadi serta membantu orang tua maupun orang lain. Sejalan dengan Peraturan Presiden Nomor 87 Tahun 2017 tentang Penguatan Pendidikan Karakter (PPK).

\subsection{Nilai-Nilai Pendidikan Karakter Yang Tertanam Pada Siswa Melalui Program Paku Bumi}

Nilai-nilai karakter yang mendominasi pada kegiatan shalat fardhu dan shalat sunnah yaitu religius, nasionalis, dan integritas. Sejalan dengan Kemendikbud (2018) tentang nilainilai utama dalam gerakan penguatan pendidikan karakter yaitu meliputi religius, nasionalis, mandiri, gotong royong, dan integritas. Terdapat tiga nilai utama yang muncul dalam shalat fardhu dan shalat sunnah sesuai kemendikbud yaitu religius, nasionalis, dan integritas.

Nilai-nilai karakter yang mendominasi pada kegiatan dzikir dan doa setelah salat serta doa sehari-hari yaitu religius, nasionalis, dan integritas. Sejalan dengan Kemendikbud (2018) tentang nilai-nilai utama dalam gerakan penguatan pendidikan karakter yaitu meliputi religius, nasionalis, mandiri, gotong royong, dan integritas. Terdapat tiga nilai utama yang muncul dalam dzikir dan doa setelah salat serta doa sehari-hari sesuai kemendikbud yaitu religius, nasionalis, dan integritas.

Nilai-nilai karakter yang mendominasi pada kegiatan membaca Al-Quran dan hafal juz 30 yaitu religius, nasionalis, dan integritas. Sejalan dengan Kemendikbud (2018) tentang nilainilai utama dalam gerakan penguatan pendidikan karakter yaitu meliputi religius, nasionalis, mandiri, gotong royong, dan integritas. Terdapat tiga nilai utama yang muncul dalam dzikir dan doa setelah salat serta doa sehari-hari sesuai kemendikbud yaitu religius, nasionalis, dan integritas.

Nilai-nilai karakter yang mendominasi pada kegiatan menebar salam yaitu religius dan integritas. Sejalan dengan Kemendikbud (2018) tentang nilai-nilai utama dalam gerakan penguatan pendidikan karakter yaitu meliputi religius, nasionalis, mandiri, gotong royong, dan integritas. Terdapat dua nilai utama yang muncul dalam menebar salam sesuai kemendikbud yaitu religius dan integritas.

Nilai-nilai karakter yang mendominasi pada kegiatan puasa Ramadhan dan puasa sunnah yaitu religius dan integritas. Sejalan dengan Kemendikbud (2018) tentang nilai-nilai utama dalam gerakan penguatan pendidikan karakter yaitu meliputi religius, nasionalis, mandiri, gotong royong, dan integritas. Terdapat dua nilai utama yang muncul dalam puasa Ramadhan dan puasa sunnah sesuai kemendikbud yaitu religius dan integritas.

Nilai-nilai karakter yang mendominasi pada kegiatan akhlakul karimah yaitu religius, nasionalis, dan integritas. Sejalan dengan Kemendikbud (2018) tentang nilai-nilai utama dalam gerakan penguatan pendidikan karakter yaitu meliputi religius, nasionalis, mandiri, gotong royong, dan integritas. Terdapat tiga nilai utama yang muncul dalam akhlakul karimah sesuai kemendikbud yaitu religius, nasionalis, dan integritas.

Nilai-nilai karakter yang mendominasi pada kegiatan akhlakul karimah yaitu religius, nasionalis, dan integritas. Sejalan dengan Kemendikbud (2018) tentang nilai-nilai utama dalam gerakan penguatan pendidikan karakter yaitu meliputi religius, nasionalis, mandiri, gotong 
royong, dan integritas. Terdapat lima nilai utama yang muncul dalam life skill atau kecakapan hidup sesuai kemendikbud yaitu religius, nasionalis, mandiri, gotong royong, dan integritas.

\subsection{Faktor Pendukung Dan Penghambat Program Paku Bumi}

Pada saat melaksanakan program PAKU BUMI yang telah dicanangkan oleh MIN 1 Kota Malang perlunya dukungan dari pihak madrasah, guru dan orang untuk menyukseskan program PAKU BUMI. beberapa faktor yang menjadi pendukung pada program PAKU BUMI Faktor pendukung di MIN 1 Kota Malang dalam program PAKU BUMI tersebut diantaranya sumber daya manusia yang dimana semua pihak yang terlibat dalam program PAKU BUMI khususnya pendidik MIN 1 Kota Malang dalam menanamkan pendidikan karakter melalui program PAKU BUMI. Kepedulian dan kerjasama yang baik; yang dimana pihak madrasah dengan dibuatkan program yang jelas dan rinci, kompetensi dan materi dirancang sesuai jenjangnya, kesepahaman perihal kompetensi dan materinya yang sejalan dengan kurikulum, kerjasama yang baik antara pihak satu dengan pihak lain agar mendapatkan dukungan positif. Sarana dan prasarana yang mendukung yang dimana sarana yang dibutuhkan seperti teknologi informasi berupa handphone, laptop, atau komputer dan internet terpenuhinya fasilitasfasilitas ini menjadikan faktor pendukung dalam implementasi program PAKU BUMI.

Tidak semua yang telah direncanakan oleh manusia akan berjalan dengan lancar tanpa halangan, semua rencana pasti akan mendapat hambatan dan rintangan dalam mencapai tujuan yang telah ditentukan. Program PAKU BUMI di MIN 1 Kota Malang pun tidak terlepas dari hambatan. Menurut data yang telah didapat peneliti ada beberapa faktor yang menjadi penghambat pada program PAKU BUMI yang cenderung berasal dari luar madrasah itu sendiri, faktor-faktor penghambat tersebut diantaranya (a) siswa tidak tepat waktu dalam mengisi link google form; (b) orang tua yang kurang memiliki waktu untuk anak.

\subsection{Perilaku Siswa Sebagai Dampak Dari Implementasi Program Paku Bumi}

Banyak siswa yang merasakan dampak dari implementasi program PAKU BUMI yang disusun oleh MIN 1 Kota Malang khususnya pada perilaku siswa MIN 1 Kota Malang. Menurut Nashir (2013) terdapat beberapa nilai perilaku diantaranya yaitu perilaku jujur, perilaku tanggung jawab, perilaku disiplin, dan perilaku mandiri.

Siswa MIN 1 Kota Malang memiliki perilaku jujur dalam mengisi laporan sesuai dengan apa yang dilakukan, jika tidak melakukan kegiatan sesuai jadwal, maka siswa melaporkan sesuai realitanya. Seperti kegiatan puasa Ramadhan yang dimana siswa jujur mengakui melaksanakan puasa Ramadhan setengah hari. Hal ini sejalan dengan pendapat Nashir (2013) orang yang jujur akan berbuat benar dalam ucapan dan juga tindakan tanpa tergantung pada orang lain dan keadaan sekitar. Karena kejujuran akan menjadikan orang yang selalu dipercaya dalam perkataan, tindakan dan pekerjaan. Hal inilah kejujuran harus ditanamkan agar menjadikan pribadi yang lebih baik.

Siswa MIN 1 Kota Malang memiliki perilaku tanggung jawab, dimana siswa Melaksanakan sholat, mengaji, berpuasa, membantu orang tua untuk membersihkan rumah, menjaga lingkungan dengan membuang sampah pada tempatnya, dan menjalankan tugasnya sebagai siswa, Hal ini sejalan dengan pendapat Nashir (2013) bahwa tanggung jawab adalah kesadaran dari dalam diri seseorang untuk melaksanakan tugas atau kewajibannya. Tanggung jawab pada anak harus dilatih terus menerus agar menetap dalam diri. Tanggung jawab dapat 
diwujudkan melalui proses pelatihan yang intensif sejak dini melalui pengalaman atau belajar, pembiasaan, dan praktik dalam kehidupan sehari-hari. Hal tersebut yang menjadikan program PAKU BUMI sebagai program yang membentuk karakter pada siswa MIN 1 Kota Malang.

Perilaku disiplin sebagai dampak implementasi program PAKU BUMI seperti siswa mengerjakan kewajibannya sebagai umat beragama Islam. Saat melaksanakan sholat, siswa sholat di awal waktu setelah adzan berkumandang. Saat pelaksanaan pondok Ramadhan, siswa juga antre untuk berwudhu dan menata barisan sholat, dimana hal tersebut mengajarkan siswa untuk melatih kedisiplinan diri dan juga melatih kesabaran. Siswa juga disiplin dalam mengisi laporan program PAKU BUMI di google form yang sesuai jadwal. Disiplin harus dilatih sedini mungkin agar menetap pada diri manusia, sehingga manusia akan sadar pada hal atau kegiatan yang dilakukan. Hal ini sejalan dengan Nashir (2013) disiplin lahir dari kesadaran diri seseorang bukan karena paksaan. Kehidupan sehari-hari mulai dari kecil hingga besar memerlukan kedisiplinan agar membawa dampak yang baik bagi diri sendiri maupun orang lain.

Banyak kegiatan yang menunjukkan kemandirian pada siswa MIN 1 Kota Malang seperti siswa diantar sampai depan gerbang madrasah, siswa memakai mukena sendiri saat kegiatan sholat dhuha berjamaah, siswa melepas dan memakai sepatu sendiri, siswa rajin membersihkan kamar tidurnya, siswa rajin membersihkan rumah. Hal tersebut yang membuat siswa lebih mandiri dalam melaksanakan kegiatan pada dirinya. Terlihat bahwa siswa dengan sigap melakukan kegiatan untuk dirinya tanpa menggantungkan orang lain. Sejalan dengan pendapat Nashir (2013) perilaku mandiri merupakan potensi diri seseorang dengan kemandiriannya untuk mengembangkan kemampuan dirinya.

\section{Simpulan}

Program PAKU BUMI merupakan kegiatan intrakurikuler yang dibuat oleh MIN 1 Kota Malang dengan konsep program yang berasal dari kurikulum nasional Kementerian Agama, visi misi MIN 1 Kota Malang, dan surat edaran dari Kementrian Agama Kota Malang. Pada perencanaan program PAKU BUMI membentuk koordinator unit program PAKU BUMI untuk mempermudah dan merealisasikan program PAKU BUMI yang dilakukan selama dua minggu sekali dan berjalan setiap semester dari tahun 2020. Materi berdasarkan pada KI 1 dan KI 2 dan dibuat sesuai karakteristik madrasah agar dapat dispesifikan lagi sesuai kebutuhan MIN 1 Kota Malang. Program PAKU BUMI ini sudah mencerminkan nilai-nilai pendidikan karakter yang tertera pada Permendiknas (2010:9-10) maupuan Kemendikbud (2017:8-9). Implementasi program PAKU BUMI dalam konteks penguatan pendidikan karakter di MIN 1 Kota Malang memiliki berbagai macam kegiatan dalam menanamkan karakter bagi siswanya. Kegiatan yang ditanamkan oleh MIN 1 Kota Malang untuk menerapkan karakter siswanya dari kegiatan shalat fardhu dan shalat sunnah, dzikir dan doa setelah salat serta doa sehari-hari, membaca Al-Quran dan hafal juz 30, menebar salam, menebar salam, akhlakul karimah, dan life skill atau kecakapan hidup. Penerapannya dilakukan secara terus menerus sesuai jadwal yang disusun oleh MIN 1 Kota Malang dengan tujuan untuk menanamkan pendidikan karakter. Nilai-nilai karakter yang tertanam pada program PAKU BUMI dalam diri siswa tercakup dalam lima nilai utama dalam program penguatan pendidikan karakter yang terdiri dari nilai religius, nilai nasionalisme, nilai mandiri, nilai gotong royong, dan nilai integritas. Terdapat beberapa faktor yang mendukung dalam program PAKU BUMI di MIN 1 Kota Malang yang berasal dari dalam sekolah maupun dari luar sekolah itu sendiri. Faktor pendukung program PAKU BUMI di MIN 1 Kota Malang yaitu (a) sumber daya manusia; (b) kepedulian dan kerjasama yang baik; 
(c) sarana dan prasarana yang mendukung. Adapun faktor penghambat program PAKU BUMI di MIN 1 Kota Malang yaitu (a) siswa tidak tepat waktu dalam mengisi link google form: (b) orang tua yang kurang memiliki waktu untuk anak. Siswa MIN 1 Kota Malang telah menunjukkan perilaku dengan diterapkannya pendidikan karakter melalui program PAKU BUMI yang disusun oleh MIN 1 Kota Malang. Hal tersebut terbukti dari perilaku siswa yang jujur, tanggung jawab, disiplin, dan mandiri.

\section{Daftar Rujukan}

Akbar, S. (2015). Pendidikan Karakter: Best Practice. Malang: Universitas Negeri Malang.

Akbar, S. (2011). Revitalisasi Pendidikan Karakter di Sekolah Dasar. Malang: Universitas Negeri Malang.

Akbar, S. (2010). Model Pembelajaran Nilai dan Karakter Berbasis Nilai-nilai Kehidupan di Sekolah Dasar. Jurnal Ilmu Pendidikan (JIP), 17(1).

Nashir, H. (2013). Pendidikan Karakter berbasis Agama dan Kebudayaan. Yogyakarta: Multi Presindo.

Novita, M. (2017). Sarana dan prasarana yang baik menjadi bagian ujung tombak keberhasilan lembaga pendidikan islam. Nur El-Islam, 4(2), 97-129

Shafura, H. R. A. (2018). Kerjasama Antara Sekolah Dengan Orang Tua Dalam Pendidikan Karakter di SD Muhammadiyah Al-Mujahidin Wonosari. Basic Education, 7(34), 3-366.

Wahyudi, A. (2016). Implementasi Rencana Strategis Badan Pemberdayaan Masyarakat dan Desa dalam Upaya Pengembangan Badan Usaha Milik Desa di Kabupaten Kotawaringin Barat. Jurnal Ilmiah Administrasi Publik, 2(2), 101-105. 